\title{
Four years of monitoring for viral haemorrhagic septicaemia virus in marine waters around the United Kingdom
}

\author{
P. F. Dixon ${ }^{1, *}$, S. Avery ${ }^{2}$, E. Chambers ${ }^{1}$, S. Feist ${ }^{1}$, H. Mandhar ${ }^{2}$, L. Parry ${ }^{3}$, \\ D. M. Stone ${ }^{1}$, H. K. Strømmen ${ }^{4}$, J. K. Thurlow ${ }^{2}$, C. Tsin-yee Lui ${ }^{4}$, K. Way ${ }^{1}$ \\ ${ }^{1}$ CEFAS Weymouth Laboratory, Barrack Road, The Nothe, Weymouth DT4 8UB, United Kingdom \\ ${ }^{2}$ Department of Pharmaceutical and Biological Sciences, Aston University, Birmingham B4 7ET, United Kingdom \\ ${ }^{3}$ University of Wales, College of Cardiff, Cardiff CF1 3TE, Wales, United Kingdom \\ ${ }^{4}$ School of Biological Sciences, University of Surrey, Guildford GU2 5XH, United Kingdom
}

\begin{abstract}
Between 1995 and 1998, marine fish from around the coast of the UK were collected and samples analysed for viral haemorrhagic septicaemia virus (VHSV) using cell culture isolation methods. In 1997 and 1998 the samples were also analysed for VHSV by reverse transcription PCR (RT-PCR). A total of 1867 fish of 11 species were tested, but VHSV was isolated on only 1 occasion, from herring Clupea harengus, in 1996 . However, despite VHSV not being isolated in 1997 and 1998, in both years samples of herring from the west and south coasts of England produced positive signals in the RT-PCR, and in 1997 cod from the east coast of England also produced positive signals in the RT-PCR. These results are believed to be true indications of the presence of VHSV nucleic acid in the fish. In 1997, birnaviruses from Serogroup B1 were isolated from herring (a previously unrecorded host for the virus) and cod Gadus morhua, and a birnavirus from Serogroup A2 was also isolated from cod. In 1998, an aquareovirus was isolated from haddock Melanogrammus aeglefinus, a previously unrecorded host for the virus.
\end{abstract}

KEY WORDS: Viral haemorrhagic septicaemia virus · VHSV · Birnavirus · Aquareovirus · Marine fish · UK $\cdot$ Survey

\section{INTRODUCTION}

Marine-fish disease monitoring around the United Kingdom has been undertaken by staff of the CEFAS Weymouth Laboratory on an annual basis since 1982. The dab Limanda limanda is the target species and the incidence and prevalence of external disease conditions (lymphocystis, papillomas, hyperpigmentation and ulcers) and liver pathology are monitored according to international guidelines (Bucke et al. 1996). Diseases in other species, such as Ichthyophonus in Atlantic herring Clupea harengus and pseudobranch 'tumours' in Atlantic cod Gadus morhua, are also monitored. Between 1995 and 1998, fish other than dab were sampled and tested for the presence of viral haemorrhagic septicaemia virus (VHSV), primarily because of an increasing awareness of the potential for transfer of viruses from wild fish to fish in marine aquaculture, but also to broaden the knowledge of the health status of marine fish. The main impetus for this was reports that VHSV had been identified in a number of marine fish species (Meier et al. 1994, Meyers \& Winton 1995), and that VHSV from a marine fish reservoir might have been responsible for a VHS outbreak in turbot Scophthalmus maximus cultivated on the Scottish island of Gigha (Munro 1996). The results of these annual surveys complement others conducted over a similar time period in different UK waters and in different areas of the North Sea (Smail 1995, 2000, Mortensen et al. 1999, King et al. 2001). We have previously described the isolation of VHSV from herring C. harengus during one of the cruises (Dixon et al. 
1997), and we report here the full results of the virus monitoring between 1995 and 1998.

\section{MATERIALS AND METHODS}

Fish sampling. Fish were caught during January or February using a Granton trawl or a beam trawl. The sampling sites are shown in Fig. 1 and the species tested are shown in Table 1 ; between 1 and 4 trawl tows were made at each sampling site. In some years certain sites could not be sampled because of adverse weather conditions. Each species from a trawl tow were sampled separately and portions of liver, spleen, heart, kidney and brain were taken from each fish, up to a maximum of 50 fish per species per station. Organs from the first 10 fish of a species were put into 10 separate sample containers, and then organs from the next 10 fish of that species were added sequentially to those sample containers; according to the number of fish of a species available at a station, samples comprised from 1 fish to a maximum of 10 pools each of 5 fish. The tissue samples were covered with virus transport medium then blast frozen; they were stored frozen at $20^{\circ} \mathrm{C}$ for up to 2 mo until they were processed at the laboratory. In 1997, 5 hypermelanised and 5 normal appearing dab from one site were processed individually, and 5 hypermelanised dab from a second site were also processed individually. In 1996, 1 cod, and in $19982 \mathrm{cod}$, from different sites were seen to have skin ulcers, and were processed individually. Skin with underlying muscle as well as internal organs were taken from those dab and cod. Portions of tissues showing pathologies were fixed in $10 \%$ neutral buffered formalin, processed and stained with haematoxylin and eosin (H\&E) using standard histological procedures.

Cell cultures. Between 1995 and 1997, Epithelioma papulosum cyprini (EPC) (Fijan et al. 1983) and bluegill fibroblast (BF-2) (American Type Culture Collection, ATCC CCL 91) cells were used; however in 1998, fathead minnow (FHM) (ATCC CCL 42) and chinook salmon embryo (CHSE214) (ATCC CRL 1681) cells were also used. In that year the samples were diluted to 1:100 and 1:1000 and inoculated onto each cell type with and without pre-treatment of the cell monolayers with $7 \%$ polyethylene glycol (PEG) 20000 for 30 min (Batts \& Winton 1989). After $7 \mathrm{~d}$ the samples were passaged either with or without PEG pre-treatment according to the initial inoculation.

In 1998, samples that were positive for VHSV by reverse transcription PCR (RT-PCR) but negative for the virus in the above cell cultures were also inoculated onto the following cell lines: rainbow trout gonad (RTG-2) (ATCC CCL 55), Atlantic salmon (AS) (Nicholson \& Byrne 1973), striped snakehead (SSN-1) (Frerichs et al. 1991), rainbow trout embryo (RTE) and turbot fin (TF) (the latter 2 cell lines, R. F. Williams,

Table 1. Total numbers of marine fish tested for viruses from the 4 research cruises

\begin{tabular}{|lrrrrr|}
\hline Fish species & \multicolumn{3}{c}{ Year } & & \multirow{2}{*}{ Total } \\
& 1995 & 1996 & 1997 & 1998 & \\
\hline Brill Scophthalmus rhombus & & & & 5 & 5 \\
Cod Gadus morhua & 20 & 168 & 217 & 303 & 708 \\
Dab Limanda limanda & & & 15 & & 15 \\
Haddock Melanogrammus aeglefinus & & 1 & 13 & 51 & 65 \\
Herring Clupea harengus & 10 & 50 & 237 & 236 & 533 \\
Poor cod Trisopterus minutus & & 3 & & & 3 \\
Saithe Pollachius virens & & & & 1 & 1 \\
Scad Trachurus trachurus & & & & 7 & 7 \\
Sea trout Salmo trutta & & & & 43 & 1 \\
Sprat Sprattus sprattus & & 1 & 2 & 8 & 11 \\
Turbot Scophthalmus maximus & 301 & 120 & 49 & 5 & 475 \\
Whiting Merlangius merlangus & 331 & 343 & 533 & 660 & 1867 \\
Total & & & & & \\
\hline
\end{tabular}

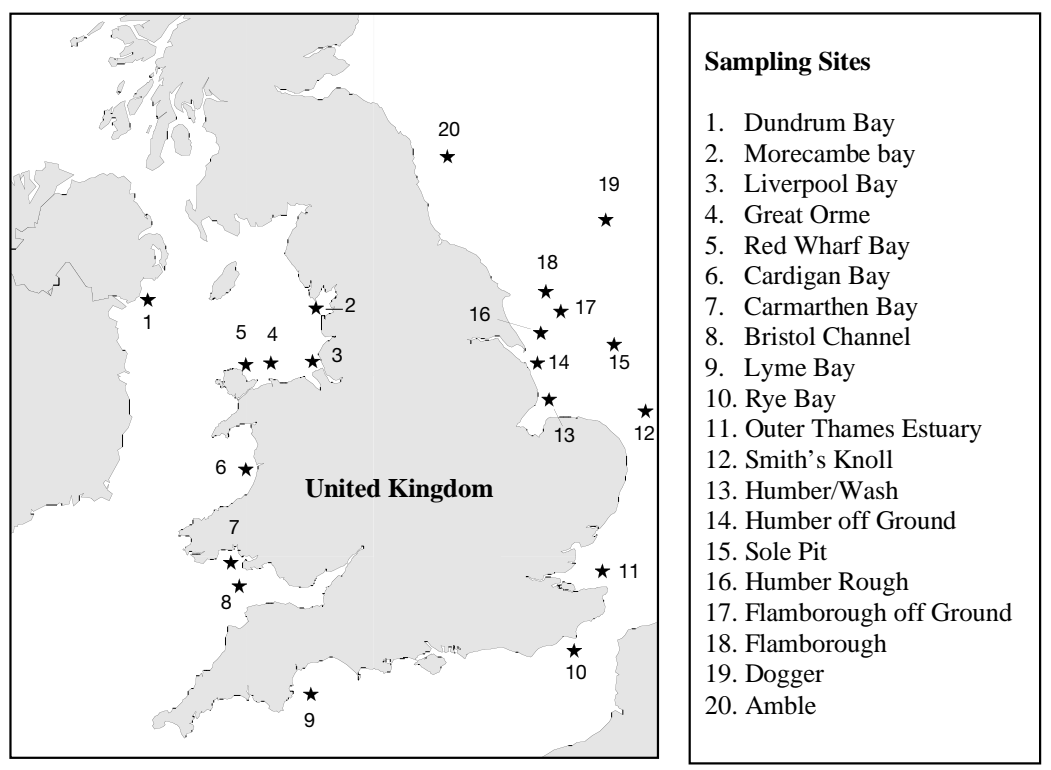

Fig. 1. Sampling sites ( $\star$ ) for marine fish surveys from 1995 to 1998 
CEFAS laboratory, unpubl.). Those cell lines had been selected as they were known to support the replication of VHSV (Jensen 1965, P. F. Dixon \& L. Parry unpubl. data), and would broaden the spectrum of susceptible cell lines inoculated with samples known to harbour VHSV nucleic acid. Inoculation was as described above but without PEG pre-treatment. After $7 \mathrm{~d}$ the samples were blind passaged at 1:10 and 1:100 dilutions, both in the standard manner and by inoculating cells in suspension. To effect this the passage, inoculum was diluted to $1: 5$ and 1:50 and dispensed into wells of a cell culture multi-well plate. An equal volume of seed cells were added to each well, and the multi-well plates were gently shaken for 1 to $2 \mathrm{~min}$ before being transferred to an incubator, where the cells attached themselves to bottom of the plastic culture vessel as usual.

Sample processing. Tissues were processed by the method stipulated by the Commission of the European Communities (CEC) for detecting VHSV (CEC 1992, 1996) as described by Dixon et al. (1997). On blind passage, the cells were observed for up to 4 wk unless a cytopathic effect (CPE) was seen before then. The processing was done in a microbiological safety cabinet to reduce the risk of both cross-contamination or laboratory contamination of the samples.

The tissue extracts were also tested for the presence of VHSV nucleic acid sequences by RT-PCR.

Virus identification. Cell cultures showing CPE suggestive of rhabdoviruses or birnaviruses were tested in ELISAs for VHSV, infectious haematopoietic necrosis virus (IHNV) (Way \& Dixon 1988, Way 1996) and birnavirus Serotype A2 (Dixon \& Hill 1983) to ascertain the presence of those viruses. The latter ELISA was modified by changing the enzyme from alkaline phosphatase to horseradish peroxidase and then performed as described by Way \& Dixon (1988) and Way (1996). Identification of VHSV in infected cell cultures was also done by RT-PCR. Viruses not identified by the ELISAs were then tested by neutralisation with birnavirus antisera, using the constant antisera, variable virus method (Rovozzo \& Burke 1973), as birnaviruses are widespread in the marine environment. Antisera against the viruses, with homologous $50 \%$ plaque neutralisation titres of at least $10^{6}$, were diluted to $5 \times 10^{-2}$ and mixed with equal volumes of virus diluted from $5 \times$ $10^{-1}$ to $5 \times 10^{-9}$. After incubation at room temperature for $1 \mathrm{~h}$, aliquots of the mixture were inoculated onto cell monolayers according to the cell type in which the $\mathrm{CPE}$ was observed. The cells were incubated at $15^{\circ} \mathrm{C}$ for $7 \mathrm{~d}$ then observed for the presence of CPE. This preliminary identification was confirmed by plaque neutralisation as described by Dixon \& de Groot (1996).

The CPE produced by one sample was suggestive of an aquareovirus. In order to short-cut the identifica- tion process, the tests initially used to identify the cause of the CPE (electron microscopy and electrophoresis of RNA) were directed at supporting that suggestion.

RT-PCR. Total RNA was extracted from $200 \mu \mathrm{l}$ cell culture supernatant, or from $100 \mu \mathrm{l}$ of the initial 1:10 dilution of homogenised tissue using the Trizol $^{\mathrm{TM}}$ reagent; the reverse transcription step utilised onetenth of the total RNA extracted from the tissue (i.e. $1 \mathrm{mg}$ ). The semi-nested RT-PCR for VHSV was carried out as previously described (Dixon et al. 1997, Strømmen \& Stone 1998) using F3 (5'-GAT-CAG-GTC-CCCCAR-RTC-NGT-3') in place of F2 in the first round of RT-PCR. In 1996 only those fish samples from which virus was isolated were tested by RT-PCR, but all the 1997 and 1998 samples were screened for the presence of VHSV nucleic acid.

Nucleotide sequencing. RT-PCR products were purified using the GLEANCLEAN ${ }^{\circledR}$ (Anachem) and inserted into the pGEM-T vector (Promega) using the standard protocol. Both DNA strands were sequenced using the M13 universal sequencing primers and the ABI PRISM ${ }^{\mathrm{TM}}$ dye terminator cycle sequencing system (Applied Biosystems). Sequencing reactions were analysed on an ABI 310 genetic analyser and multiple alignments performed using Clustal V (Higgins \& Sharp 1989).

Reference viruses. The aquareovirus $13 p_{2}$, originally isolated from the American oyster Crassostrea virginica (Meyers 1979), was a gift from Dr. T. Meyers, Juneau Fish Pathology Laboratory, Alaska. Brown trout reovirus (BTR) was isolated at the CEFAS laboratory from brown trout Salmo trutta (Taylor et al. 1998). Birnavirus reference Serotype A2 (Jørgensen \& Bregnballe 1969) was a gift from the late Dr. P. E. V. Jørgensen, and reference Serotype B1 had been isolated at the CEFAS laboratory (Hill 1976, Hill \& Way 1995). VHSV isolates H17/5 and H19/1 (Smail 2000) were gifts from Dr. D. Smail, Fisheries Research Services, Marine Laboratory, Aberdeen, and VHSV isolate cod ulcus (= cod rhabdo 79) (Jørgensen \& Olesen 1987) was a gift from Dr. N. Olesen, Danish Veterinary Laboratory, Aarhus, Denmark. VHSV isolate 96-43 was isolated at the CEFAS laboratory (Dixon et al. 1997).

Virus concentration. For electron microscopy, $2 \times$ $175 \mathrm{~cm}^{2}$ flasks of CHSE-214 cells showing gross CPE were frozen at $-20^{\circ} \mathrm{C}$, thawed and cell debris removed by centrifugation at $1500 \times g$ for $10 \mathrm{~min}$ at $4^{\circ} \mathrm{C}$. The viruses were concentrated by adding sodium chloride to $2.2 \%$ and PEG 6000 to $7 \%$ to the supernatant. The mixture was stirred overnight at $4^{\circ} \mathrm{C}$ then centrifuged at $2000 \times g$ for $1 \mathrm{~h}$ at $4^{\circ} \mathrm{C}$. The pellets were resuspended in distilled water $(0.5 \mathrm{ml}$ total $)$ and an equal volume of 1,1,2-trichloro-1,1,2-trifluoroethane was 
added and mixed thoroughly. The mixture was separated into phases by centrifugation at $1000 \times g$ for 5 min at $4{ }^{\circ} \mathrm{C}$. The upper aqueous phase was removed and examined by electron microscopy.

For RNA extraction, a single $175 \mathrm{~cm}^{2}$ flask of CHSE-214 cells showing gross $\mathrm{CPE}$ was frozen at $-20^{\circ} \mathrm{C}$, thawed, and concentrated by centrifugation at $90000 \times g$ for $1 \mathrm{~h}$ at $4^{\circ} \mathrm{C}$. The pellet was resuspended in $300 \mu \mathrm{l}$ molecularbiology grade distilled water (Merck) and processed as described below.

Electron microscopy. Concentrated virus was applied to carbon-coated Formvar grids, stained with $2 \%$ methylamine tungstate and observed with a JEOL 1210 transmission electron microscope.

RNA extraction and electrophoresis. A mixture of $4 \mu \mathrm{l}$ of RNAsin ${ }^{\circledR}$ (Promega), $15 \mu \mathrm{l}$ 10\% sodium lauryl sulphate (SDS), and $15 \mu$ l Proteinase K was added to $300 \mu$ l of concentrated virus, mixed and incubated at $37^{\circ} \mathrm{C}$ for $1 \mathrm{~h}$. A further $17.5 \mu \mathrm{l} 10 \% \operatorname{SDS}$ and $1.2 \mu \mathrm{l} 3 \mathrm{M}$ sodium acetate, $10.3 \mu \mathrm{lmol}$ ecular-biology grade distilled water and $6 \mu$ lithium chloride were then added. After mixing, $300 \mu \mathrm{l}$ phenolchloroform-iso amyl alcohol (PCIA) (24:24:1) (Gibco BRL) were added, mixed, and a further $40 \mu \mathrm{l} 3 \mathrm{M}$ sodium acetate were added. The preparation was mixed then centrifuged at $13000 \times$ $g$ for $15 \mathrm{~min}$ at room temperature. The upper aqueous layer was transferred to another tube and $300 \mu$ PCIA was added, mixed and centrifuged as before. The aqueous layer was transferred to a further tube, $1 \mathrm{ml}$ absolute ethanol was added and the tube was kept at $-20^{\circ} \mathrm{C}$ overnight to precipitate the RNA. The RNA was centrifuged to a pellet at $13000 \times g$ for $30 \mathrm{~min}$ at room temperature after which the ethanol was aspirated from the tube, and residual ethanol was allowed to evaporate. The pellet was resuspended in $20 \mu \mathrm{l}$ diethyl pyrocarbonatetreated water.

The RNA was analysed on $6 \%$ polyacrylamide gels (approximately $10 \times 7 \mathrm{~cm}$ ) prepared from a stock solution of $30 \%$ acrylamide and bis-acrylamide (29:1) in tris-borate buffer. Electrophoresis was carried out for $10 \mathrm{~min}$ at $50 \mathrm{~V}$ then $1.5 \mathrm{~h}$ at $200 \mathrm{~V}$. The gels were fixed and stained using a silver stain kit (Silver Stain Plus, BioRad) according to the manufacturer's instructions.
Table 2. Locations of fish sampled for virus isolation in 1995. Sampling site numbers correspond to those in Fig. 1

\begin{tabular}{|lclc|}
\hline Sampling site & Location & \multicolumn{1}{c}{$\begin{array}{c}\text { Fish } \\
\text { sampled }\end{array}$} & $\begin{array}{c}\text { Number } \\
\text { tested }\end{array}$ \\
\hline 12 Morecambe Bay & $53^{\circ} 56.51^{\prime} \mathrm{N}, 03^{\circ} 23.64^{\prime} \mathrm{W}$ & Cod & 10 \\
2 Morecambe Bay & $53^{\circ} 56.51^{\prime} \mathrm{N}, 03^{\circ} 23.64^{\prime} \mathrm{W}$ & Whiting & 50 \\
1 Dundrum Bay & $54^{\circ} 08.20^{\prime} \mathrm{N}, 05^{\circ} 37.27^{\prime} \mathrm{W}$ & Whiting & 40 \\
4 Great Orme & $53^{\circ} 23.09^{\prime} \mathrm{N}, 03^{\circ} 38.04^{\prime} \mathrm{W}$ & Cod & 10 \\
4 Great Orme & $53^{\circ} 23.09^{\prime} \mathrm{N}, 03^{\circ} 38.04^{\prime} \mathrm{W}$ & Whiting & 40 \\
4 Great Orme & $53^{\circ} 23.09^{\prime} \mathrm{N}, 03^{\circ} 38.04^{\prime} \mathrm{W}$ & Herring & 10 \\
6 Cardigan Bay & $52^{\circ} 21.42^{\prime} \mathrm{N}, 04^{\circ} 54.23^{\prime} \mathrm{W}$ & Whiting & 42 \\
18 Flamborough & $54^{\circ} 15.59^{\prime} \mathrm{N}, 00^{\circ} 27.06^{\prime} \mathrm{E}$ & Whiting & 79 \\
15 Sole Pit & $53^{\circ} 45.96^{\prime} \mathrm{N}, 01^{\circ} 24.04^{\prime} \mathrm{E}$ & Whiting & 50 \\
\hline
\end{tabular}

Table 3. Locations of fish sampled for virus isolation in 1996. Sampling site numbers correspond to those in Fig. 1

\begin{tabular}{|lclc|}
\hline Sampling site & Location & \multicolumn{1}{c}{$\begin{array}{c}\text { Fish } \\
\text { sampled }\end{array}$} & $\begin{array}{c}\text { Number } \\
\text { tested }\end{array}$ \\
\hline 15 Sole Pit & $53^{\circ} 38.81^{\prime} \mathrm{N}, 01^{\circ} 32.90^{\prime} \mathrm{E}$ & Cod & 6 \\
13 Humber/Wash & $53^{\circ} 18.08^{\prime} \mathrm{N}, 00^{\circ} 26.71^{\prime} \mathrm{E}$ & Cod & $49^{\mathrm{a}}$ \\
18 Flamborough & $54^{\circ} 14.03^{\prime} \mathrm{N}, 00^{\circ} 31.15^{\prime} \mathrm{E}$ & Cod & 6 \\
18 Flamborough & $54^{\circ} 12.52^{\prime} \mathrm{N}, 00^{\circ} 37.45^{\prime} \mathrm{E}$ & Turbot & 1 \\
1 Dundrum Bay & $54^{\circ} 08.54^{\prime} \mathrm{N}, 05^{\circ} 47.58^{\prime} \mathrm{W}$ & Cod & 34 \\
2 Morecambe Bay & $54^{\circ} 04.31^{\prime} \mathrm{N}, 03^{\circ} 25.94^{\prime} \mathrm{W}$ & Cod & 9 \\
2 Morecambe Bay & $54^{\circ} 04.31^{\prime} \mathrm{N}, 03^{\circ} 25.94^{\prime} \mathrm{W}$ & Whiting & 20 \\
3 Liverpool Bay & $53^{\circ} 57.96^{\prime} \mathrm{N}, 03^{\circ} 23.55^{\prime} \mathrm{W}$ & Cod & 27 \\
3 Liverpool Bay & $53^{\circ} 28.67^{\prime} \mathrm{N}, 03^{\circ} 44.07^{\prime} \mathrm{W}$ & Poor-cod & 3 \\
5 Red Wharf Bay & $53^{\circ} 21.82^{\prime} \mathrm{N}, 04^{\circ} 10.38^{\prime} \mathrm{W}$ & Cod & 20 \\
6 Cardigan Bay & $52^{\circ} 15.25^{\prime} \mathrm{N}, 04^{\circ} 20.66^{\prime} \mathrm{W}$ & Whiting & 50 \\
8 Bristol Channel & $51^{\circ} 33.00^{\prime} \mathrm{N}, 04^{\circ} 42.33^{\prime} \mathrm{W}$ & Cod & 1 \\
8 Bristol Channel & $51^{\circ} 33.00^{\prime} \mathrm{N}, 04^{\circ} 42.33^{\prime} \mathrm{W}$ & Haddock & 1 \\
8 Bristol Channel & $51^{\circ} 33.00^{\prime} \mathrm{N}, 04^{\circ} 42.33^{\prime} \mathrm{W}$ & Whiting & 50 \\
10 Rye Bay & $50^{\circ} 51.71^{\prime} \mathrm{N}, 00^{\circ} 47.50^{\prime} \mathrm{E}$ & Cod & 16 \\
10 Rye Bay & $50^{\circ} 51.71^{\prime} \mathrm{N}, 00^{\circ} 47.50^{\prime} \mathrm{E}$ & Herring & 50 \\
aOne fish was ulcerated & & & \\
\hline
\end{tabular}

\section{RESULTS}

\section{5 samples}

The fish species tested are shown in Table 2. No viruses were isolated, and RT-PCR was not done on any samples as the procedure was not available at the laboratory at that time.

\section{6 samples}

The fish species tested are shown in Table 3. The isolation of VHSV from Atlantic herring in this year has already been described (Dixon et al. 1997). The RTPCR was only used to test the herring samples from the same station at which the VHSV-positive herring were taken. No other viruses were isolated. 


\section{7 samples}

The fish species tested are shown in Table 4. Dab with hypermelanisation were specifically targeted at 2 sites, but no virus of any type was isolated. However, 6 other samples exhibited CPE (Table 5), but only after a blind passage. All of the isolates were tested in the VHSV and birnavirus Serotype A2 ELISAs, and all were negative in the VHSV ELISA. However, Isolates 36-153 (Trawl 36, Sample 153) and 36-154 produced strong positive signals in the birnavirus Serotype A2 ELISA (absorbance at $450 \mathrm{~nm}$ was 0.72 and 0.70 , respectively, compared to the positive control absorbance of 0.95 and negative control absorbance of 0.13). That identification was confirmed by plaque neutralisation. Isolates 23-44, 43-160, 44-164 and 44167 were negative in the birnavirus Serotype A2 ELISA, and were also negative in the IHNV ELISA. In

Table 4. Locations of fish sampled for virus detection in 1997. Sampling site numbers correspond to those in Fig. 1

\begin{tabular}{|c|c|c|c|}
\hline Sampling site & Location & $\begin{array}{c}\text { Fish } \\
\text { sampled }\end{array}$ & $\begin{array}{c}\text { Number } \\
\text { tested }\end{array}$ \\
\hline 12 Smiths Knoll & $52^{\circ} 40.19^{\prime} \mathrm{N}, 02^{\circ} 19.76^{\prime} \mathrm{E}$ & Cod & 8 \\
\hline 15 Sole Pit & $53^{\circ} 45.96^{\prime} \mathrm{N}, 01^{\circ} 24.04^{\prime} \mathrm{E}$ & Herring & 30 \\
\hline 15 Sole Pit & $53^{\circ} 45.96^{\prime} \mathrm{N}, 01^{\circ} 24.04^{\prime} \mathrm{E}$ & Cod & 5 \\
\hline 13 Humber/Wash & $53^{\circ} 18.48^{\prime} \mathrm{N}, 00^{\circ} 25.84^{\prime} \mathrm{E}$ & Herring & 50 \\
\hline 13 Humber/Wash & $53^{\circ} 18.48^{\prime} \mathrm{N}, 00^{\circ} 25.84^{\prime} \mathrm{E}$ & Cod & 28 \\
\hline 18 Flamborough & $54^{\circ} 15.59^{\prime} \mathrm{N}, 00^{\circ} 27.06^{\prime} \mathrm{E}$ & Herring & 14 \\
\hline 18 Flamborough & $54^{\circ} 15.59^{\prime} \mathrm{N}, 00^{\circ} 27.06^{\prime} \mathrm{E}$ & Cod & 13 \\
\hline 18 Flamborough & $54^{\circ} 15.59^{\prime} \mathrm{N}, 00^{\circ} 27.06^{\prime} \mathrm{E}$ & Haddock & 2 \\
\hline 18 Flamborough & $54^{\circ} 15.59^{\prime} \mathrm{N}, 00^{\circ} 27.06^{\prime} \mathrm{E}$ & $\mathrm{Dab}$ & $10^{\mathrm{a}}$ \\
\hline 19 Dogger & $54^{\circ} 47.24^{\prime} \mathrm{N}, 01^{\circ} 17.15^{\prime} \mathrm{E}$ & Herring & 5 \\
\hline 19 Dogger & $54^{\circ} 47.24^{\prime} \mathrm{N}, 01^{\circ} 17.15^{\prime} \mathrm{E}$ & Cod & 12 \\
\hline 19 Dogger & $54^{\circ} 47.24^{\prime} \mathrm{N}, 01^{\circ} 17.15^{\prime} \mathrm{E}$ & Haddock & 1 \\
\hline 19 Dogger & $54^{\circ} 47.24^{\prime} \mathrm{N}, 01^{\circ} 17.15^{\prime} \mathrm{E}$ & Whiting & 5 \\
\hline 20 Amble & $55^{\circ} 19.23^{\prime} \mathrm{N}, 01^{\circ} 15.09^{\prime} \mathrm{W}$ & Herring & 16 \\
\hline 20 Amble & $55^{\circ} 19.23^{\prime} \mathrm{N}, 01^{\circ} 15.09^{\prime} \mathrm{W}$ & Cod & 33 \\
\hline 20 Amble & $55^{\circ} 19.23^{\prime} \mathrm{N}, 01^{\circ} 15.09^{\prime} \mathrm{W}$ & Haddock & 10 \\
\hline 3 Liverpool Bay & $53^{\circ} 28.17^{\prime} \mathrm{N}, 03^{\circ} 42.59^{\prime} \mathrm{W}$ & Herring & $50^{\mathrm{b}}$ \\
\hline 3 Liverpool Bay & $53^{\circ} 28.17^{\prime} \mathrm{N}, 03^{\circ} 42.59^{\prime} \mathrm{W}$ & Cod & 15 \\
\hline 3 Liverpool Bay & $53^{\circ} 28.17^{\prime} \mathrm{N}, 03^{\circ} 42.59^{\prime} \mathrm{W}$ & Dab & 5 \\
\hline 5 Red Wharf Bay & $53^{\circ} 21.42^{\prime} \mathrm{N}, 04^{\circ} 07.58^{\prime} \mathrm{W}$ & Herring & 50 \\
\hline 5 Red Wharf Bay & $53^{\circ} 21.42^{\prime} \mathrm{N}, 04^{\circ} 07.58^{\prime} \mathrm{W}$ & Cod & 50 \\
\hline 6 Cardigan Bay & $52^{\circ} 21.85^{\prime} \mathrm{N}, 04^{\circ} 54.23^{\prime} \mathrm{W}$ & Whiting & 24 \\
\hline 7 Carmarthen Bay & $51^{\circ} 32.49^{\prime} \mathrm{N}, 04^{\circ} 46.30^{\prime} \mathrm{W}$ & Cod & 7 \\
\hline 7 Carmarthen Bay & $51^{\circ} 32.49^{\prime} \mathrm{N}, 04^{\circ} 46.30^{\prime} \mathrm{W}$ & Whiting & $10^{\mathrm{c}}$ \\
\hline 7 Carmarthen Bay & $51^{\circ} 32.49^{\prime} \mathrm{N}, 04^{\circ} 46.30^{\prime} \mathrm{W}$ & Turbot & 1 \\
\hline 9 Lyme Bay & $50^{\circ} 33.34^{\prime} \mathrm{N}, 03^{\circ} 12.62^{\prime} \mathrm{W}$ & Herring & $14^{\mathrm{b}}$ \\
\hline 9 Lyme Bay & $50^{\circ} 33.34^{\prime} \mathrm{N}, 03^{\circ} 12.62^{\prime} \mathrm{W}$ & Cod & 1 \\
\hline 9 Lyme Bay & $50^{\circ} 33.34^{\prime} \mathrm{N}, 03^{\circ} 12.62^{\prime} \mathrm{W}$ & Whiting & 10 \\
\hline 10 Rye Bay & $50^{\circ} 50.79^{\prime} \mathrm{N}, 00^{\circ} 45.82^{\prime} \mathrm{E}$ & Herring & $8^{\mathrm{b}}$ \\
\hline 10 Rye Bay & $50^{\circ} 50.79^{\prime} \mathrm{N}, 00^{\circ} 45.82^{\prime} \mathrm{E}$ & Cod & $34^{\mathrm{c}}$ \\
\hline 10 Rye Bay & $50^{\circ} 50.79^{\prime} \mathrm{N}, 00^{\circ} 45.82^{\prime} \mathrm{E}$ & Turbot & 1 \\
\hline 11 Outer Thames Estuary & $52^{\circ} 02.54^{\prime} \mathrm{N}, 02^{\circ} 06.07^{\prime} \mathrm{E}$ & Cod & 11 \\
\hline \multicolumn{4}{|c|}{$\begin{array}{l}{ }^{a} \text { Five fish were hypermelanised } \\
{ }^{b} \text { One fish had a granular spleen } \\
\\
{ }^{c} \text { One fish had a head ulcer }\end{array}$} \\
\hline
\end{tabular}

Table 5. 1997 research cruise. Fish from which the tissue extracts produced a cytopathic effect (CPE) following inoculation onto cell cultures. Sampling site numbers correspond to those in Fig. 1

\begin{tabular}{|lccc|}
\hline Sampling site & $\begin{array}{c}\text { Sample } \\
\text { number }\end{array}$ & Fish & $\begin{array}{c}\text { Cell line in } \\
\text { which CPE seen }\end{array}$ \\
\hline 3 Liverpool Bay & $23-44$ & Herring & BF-2 \\
7 Carmarthen Bay & $36-153$ & Cod & EPC \\
5 Red Wharf Bay & $36-154$ & Cod & EPC \\
10 Rye Bay & $43-160$ & Cod & BF-2 \\
10 Rye Bay & $44-164$ & Cod & BF-2 \\
10 Rye Bay & $44-167$ & Cod & BF-2 \\
\hline
\end{tabular}

subsequent neutralisation tests those isolates were identified as belonging to birnavirus Serogroup B. An antiserum against birnavirus B1, with a homologous $50 \%$ plaque reduction titre of $3.6 \times 10^{-6}$, had $50 \%$ plaque reduction titres of $2.6 \times 10^{-5}$ and $1.75 \times 10^{-5}$ against Isolates $23-44$ and 44-164, respectively.

All the initial 1:10 fish extracts were tested by the RT-PCR for VHSV, and 13 samples from 6 sites were positive (Table 6). Where there was sufficient product the RT-PCR results were confirmed as VHSV in origin by sequencing (Fig. 2). There were between 1 and $4(0.4$ to $1.5 \%)$ nucleotide differences between these partial sequences and the isolate from herring caught in the English Channel (96-43), and between 23 and 25 (8.7 to $9.4 \%)$ nucleotide differences when compared to the isolates from cod (H17-5 and H19-1) caught in the coastal waters east of the Shetland Islands.

The only virus isolated from any of those samples was a birnavirus from Sample 23-44. As the replication of the birnavirus may not have allowed VHSV to replicate, Sample 23-44 was re-inoculated onto BF-2 and EPC cell cultures following neutralisation of the birnavirus. Dilutions of the original homogenate were incubated for $1 \mathrm{~h}$ with an equal volume of an antiserum against birnavirus Serogroup B diluted to $5 \times 10^{-2}$, before inoculation onto the cells. No CPE was observed in the cells, even after a blind passage.

Spleens with a granular appearance from 2 herring were examined histologically. Prominent granulomas were observed, consisting of a discrete outer 


\begin{tabular}{|c|c|c|c|c|c|}
\hline & 10 & 20 & 30 & 40 & 50 \\
\hline Cod ulcus & GGCCACAAAC & GAGGCAAGCA & AGGATCACGA & GTACCCGTTC & TTCCCTGAAC \\
\hline $96-43$ & $\ldots \ldots$ & $\ldots \ldots \ldots$ & $\ldots \ldots \ldots$ & $\ldots \ldots \ldots$ & $\cdots \cdots c \cdots$ \\
\hline $\mathrm{H} 17 / 5$ & $\cdots \mathrm{G} \cdots \mathrm{T}$ & $\ldots \ldots \ldots$ & $\cdot \mathrm{A} \cdots \mathrm{C} \cdots \mathrm{T} \cdots$ & $\ldots \ldots \ldots$ & $\cdots \mathrm{T} \cdots \mathrm{T} \cdots$ \\
\hline $\mathrm{H} 19 / 1$ & $\cdots \mathrm{G} \cdots \mathrm{T}$ & $\ldots \ldots \ldots$ & $\cdot \mathrm{W} \cdot \mathrm{C} \cdots \mathrm{T} \cdot$ & $\ldots \ldots \ldots$ & $\cdots \mathrm{T} \cdots \mathrm{T} \cdots$ \\
\hline $23-41$ & $\ldots \ldots \ldots$ & $\ldots \ldots \ldots$ & $\ldots \ldots \ldots$ & $\ldots \ldots \ldots$ & $\ldots \ldots \ldots$ \\
\hline $27-51$ & $\ldots \ldots \ldots$ & $\ldots \ldots \ldots$ & $\ldots \ldots \ldots$ & $\ldots \ldots \ldots$ & $\cdots \cdots c \cdots$ \\
\hline $39-55$ & $\ldots \ldots \ldots$ & $\ldots \ldots \ldots$ & $\ldots \ldots \ldots$ & $\ldots \ldots \ldots$ & $\cdots \cdots c \cdots$ \\
\hline $3-92$ & $\ldots \ldots \ldots$ & $\ldots \ldots \ldots$ & $\cdots \cdots G \cdot$ & $\cdots \cdots \mathrm{T}^{\prime}$ & $\cdots \cdots c \cdots$ \\
\hline $13-104$ & $\ldots \ldots \ldots$ & $\ldots \ldots \ldots$ & $\ldots \ldots \ldots$ & $\ldots \ldots \ldots$ & $\cdots \cdots c \cdots$ \\
\hline \multirow[t]{2}{*}{$24-3$} & $\cdots \ldots \ldots$ & $\cdots \cdots \cdots$ & $\ldots \ldots \ldots$ & $\cdots \cdots \cdots$ & $\cdots \cdots c \cdots$ \\
\hline & 60 & 70 & 80 & 90 & 100 \\
\hline Cod ulcus & CCTCCTGCAT & CTGGATGAAA & AACAATGTCC & ATAAGGACAT & AACTCACTAT \\
\hline $96-43$ & $\ldots \ldots \ldots$ & $\ldots \ldots \ldots$ & $\ldots \ldots \ldots$ & $\ldots \ldots \ldots$ & $\ldots \ldots \ldots$ \\
\hline $\mathrm{H} 17 / 5$ & $\ldots \ldots$ & $\ldots \ldots \ldots$ & $\cdots \mathrm{T} \cdots \cdots$ & $\cdots \cdots \mathrm{T} \cdots$ & $\ldots \ldots \ldots$ \\
\hline $\mathrm{H} 19 / 1$ & $\ldots \ldots \ldots$ & $\ldots \ldots \ldots$ & $\cdots \mathrm{T} \cdots \cdots$ & $\cdots \cdots \mathrm{T} \cdot$ & $\ldots \ldots \ldots$ \\
\hline $23-41$ & $\ldots \ldots$ & $\ldots \ldots \ldots$ & $\ldots \ldots \ldots$ & $\ldots \ldots \ldots$ & $\ldots \ldots \ldots$ \\
\hline $27-51$ & $\ldots \ldots \ldots$ & $\ldots \ldots \ldots$ & $\ldots \ldots \ldots$ & $\ldots \ldots \ldots$ & $\ldots \ldots \ldots$ \\
\hline $39-55$ & $\ldots \ldots \ldots$ & $\ldots \ldots \ldots$ & $\ldots \ldots \ldots$ & $\ldots \ldots \ldots$ & $\ldots \ldots \ldots$ \\
\hline $3-92$ & $\cdots A \cdots$ & $\ldots \ldots \ldots$ & $\ldots \ldots \ldots$ & $\ldots \ldots \ldots$ & $\ldots \ldots \ldots$ \\
\hline $13-104$ & $\ldots \ldots \ldots$ & $\ldots \ldots \ldots$ & $\ldots \ldots \ldots$ & $\ldots \ldots \ldots$ & $\ldots \ldots \ldots$ \\
\hline \multirow[t]{2}{*}{$24-3$} & $\ldots \ldots \ldots$ & $\ldots \ldots \ldots$ & $\ldots \ldots \ldots$ & $\ldots \ldots \ldots$ & $\ldots \ldots \ldots$ \\
\hline & 110 & 120 & 130 & 140 & 150 \\
\hline Cod ulcus & TACAAGACCC & CAAAAACAGT & ATCGGTGGAT & CTCTACAGCA & GGAAATTTCT \\
\hline $96-43$ & $\ldots \ldots \ldots$ & $\ldots \ldots \ldots$ & $\ldots \ldots \ldots$ & $\ldots \ldots \ldots$ & $\ldots \ldots \ldots$ \\
\hline H1 $7 / 5$ & $\cdots \mathrm{T} \cdots \cdots$ & $\cdots \cdots \cdots$ & $\mathrm{C} \cdots \mathrm{T} \cdots \cdots$ & $\cdots \cdots \cdots$ & $\ldots \ldots \ldots$ \\
\hline $\mathrm{H} 19 / 1$ & $\cdots \mathrm{T} \cdots \cdots$ & $\cdots G \cdots \cdots$ & $\mathrm{C} \cdots \mathrm{T} \cdots \cdots$ & $\cdots \cdots \times$ & $\ldots \ldots \ldots$ \\
\hline $23-41$ & $\ldots \ldots \ldots$ & $\ldots \ldots \ldots$ & $\ldots \ldots \ldots$ & $\ldots \ldots \ldots$ & $\ldots \ldots \ldots$ \\
\hline $27-51$ & $\cdots \cdots \cdots$ & $\cdots \ldots \ldots$ & $\cdots \cdots \cdots$ & $\cdots \ldots \ldots$ & $\cdots \cdots \cdots$ \\
\hline $39-55$ & $\ldots \ldots \ldots$ & $\ldots \ldots \ldots$ & $\ldots \ldots \ldots$ & $\ldots \ldots \ldots$ & $\ldots \ldots \ldots$ \\
\hline $3-92$ & $\ldots \ldots \ldots$ & $\ldots \ldots \ldots$ & $\ldots \ldots \ldots$ & $\ldots \ldots \ldots$ & $\ldots \ldots \ldots$ \\
\hline $13-104$ & $\ldots \ldots \ldots$ & $\ldots \ldots \ldots$ & $\ldots \ldots \ldots$ & $\ldots \ldots \ldots$ & $\ldots \ldots \ldots$ \\
\hline \multirow[t]{2}{*}{$24-3$} & $\ldots \ldots \ldots$ & $\ldots \ldots \ldots$ & $\ldots \ldots \ldots$ & $\ldots \ldots \ldots$ & $\ldots \ldots \ldots$ \\
\hline & 160 & 170 & 180 & 190 & 200 \\
\hline Cod ulcus & CAACCCTGAT & TTCATAGAGG & GGGTTTGCAC & AACCTCGCCC & TGTCAAACTC \\
\hline $96-43$ & $\ldots \ldots \ldots$ & $\ldots \ldots \ldots$ & $\ldots \ldots \ldots$ & $\ldots \ldots \ldots$ & $\ldots \ldots \ldots$ \\
\hline $\mathrm{H} 17 / 5$ & $\mathrm{~T} \cdots \cdots$ & $\ldots \ldots \ldots$ & $\cdots \cdots \mathrm{T} \cdots$ & $G \cdots \cdots \cdots$ & $\cdots \cdot G \cdots$ \\
\hline $\mathrm{H} 19 / 1$ & $\mathrm{~T} \cdots \cdots$ & $\ldots \ldots \ldots$ & $\cdots \cdots \mathrm{T} \cdots$ & $\mathrm{G} \cdots \cdots \cdots$ & $\cdots \cdot G \cdots$ \\
\hline $23-41$ & $\ldots \ldots \ldots$ & $\cdots \ldots \ldots$ & $\cdots \cdots \cdots$ & $\cdots \cdots \cdots$ & $\cdots \ldots \ldots$ \\
\hline $27-51$ & $\ldots \ldots \ldots$ & $\ldots \ldots \ldots$ & $\ldots \ldots \ldots$ & $\ldots \ldots \ldots$ & $\ldots \ldots \ldots$ \\
\hline $39-55$ & $\ldots \ldots \ldots$ & $\ldots \ldots \ldots$ & $\ldots \ldots \ldots$ & $\ldots \ldots \ldots$ & $\ldots \ldots$ \\
\hline $3-92$ & $\ldots \ldots \ldots$ & $\ldots \ldots \ldots$ & $\ldots \ldots \ldots$ & $\ldots \ldots \ldots$ & $\ldots \ldots \ldots$ \\
\hline $13-104$ & $\ldots \ldots \ldots$ & $\ldots \ldots \ldots$ & $\ldots \ldots \ldots$ & $\ldots \ldots \ldots$ & $\cdots \ldots \ldots$ \\
\hline \multirow[t]{2}{*}{$24-3$} & $\ldots \ldots \ldots$ & $\cdots \cdots \cdots$ & $\ldots \ldots \ldots$ & $\cdots \cdots \cdots$ & $\ldots \ldots \ldots$ \\
\hline & 210 & 220 & 230 & 240 & 250 \\
\hline Cod ulcus & ATTGGCAGGG & AGTCTATTGG & GTCGGTGCCA & CACCTACAGC & CCATTGCCCC \\
\hline $96-43$ & $\ldots \ldots$ & $\ldots \ldots \ldots$ & $\ldots \ldots \ldots$ & $\ldots \ldots \ldots$ & $\ldots \ldots \ldots$ \\
\hline $\mathrm{H} 17 / 5$ & $\ldots \ldots \ldots$ & $\ldots \ldots \ldots$ & $\ldots \ldots \ldots$ & $\cdots c \cdots$ & $\cdots \cdots \mathrm{T} \cdots$ \\
\hline $\mathrm{H} 19 / 1$ & $\ldots \ldots \ldots$ & $\ldots \ldots \ldots$ & $\ldots \ldots \ldots$ & $\cdots c \cdots$ & $\cdots \cdots \mathrm{T} \cdots$ \\
\hline $23-41$ & $\ldots \ldots \ldots$ & $\ldots \ldots \ldots$ & $\ldots \ldots \ldots$ & $\ldots \ldots \ldots$ & $\ldots \ldots$ \\
\hline $27-51$ & $\ldots \ldots \ldots$ & $\ldots \ldots \ldots$ & $\ldots \ldots \ldots$ & $\ldots \ldots \ldots$ & $\ldots \ldots \ldots$ \\
\hline $39-55$ & $\ldots \ldots \ldots$ & $\ldots \ldots \ldots$ & $\ldots \ldots \ldots$ & $\ldots \ldots \ldots$ & $\ldots \ldots \ldots$ \\
\hline $3-92$ & $\ldots \ldots \ldots$ & $\cdots \ldots \ldots$ & $\ldots \ldots \ldots$ & $\cdots \cdots \cdots$ & $\cdots \ldots \ldots$ \\
\hline $13-104$ & $\ldots \ldots \ldots$ & $\ldots \ldots \ldots$ & $\ldots \ldots \ldots$ & $\ldots \ldots \ldots$ & $\ldots \ldots \ldots$ \\
\hline \multirow[t]{2}{*}{$24-3$} & $\cdots \ldots \ldots$ & $\cdots \ldots \ldots$ & $\cdots \cdots \cdots$ & $\ldots \ldots \ldots$ & $\cdots \cdots \cdots$ \\
\hline & 260 & & & & \\
\hline Cod ulcus & ACGTCGGAAA & CACTA & & & \\
\hline $96-43$ & $\ldots \ldots \ldots$ & $\ldots$ & & & \\
\hline $\mathrm{H} 17 / 5$ & $\cdots \mathrm{T} \cdots \mathrm{A} \cdots$ & $\ldots$ & & & \\
\hline $\mathrm{H} 19 / 1$ & $\cdots \mathrm{T} \cdots \mathrm{A} \cdots$ & $\cdots \cdots$ & & & \\
\hline $23-41$ & $\ldots \ldots \ldots$ & $\cdots \cdots$ & & & \\
\hline $27-51$ & $\cdots c \cdots \cdots$ & $\cdots$ & & & \\
\hline $39-55$ & $\cdots c \cdots \cdots$ & $\cdots \cdots$ & & & \\
\hline $3-92$ & $\cdots c \cdots \cdots$ & $\cdots \cdots$ & & & \\
\hline $13-104$ & $\cdots c \cdots \cdots$ & $\cdots \cdots$ & & & \\
\hline $24-3$ & $\ldots \ldots \ldots$ & $\cdots \cdots$ & & & \\
\hline
\end{tabular}

Fig. 2. Alignment of the partial sequences (nucleotides 339-663 of the glycoprotein gene) obtained for the reverse transcription PCR (RT-PCR) products described in Tables 6 and 8. Published sequences for the viral haemorrhagic septicaemia virus (VHSV) isolates from cod caught in the coastal waters east of the Shetland Islands (H17/5 and H19/1) were also included (Stone et al. 1997). ( $\cdot$ ) indicates the positions of sequence identity compared to the published sequence for the cod ulcus virus (Stone et al. 1997). Multiple alignments were performed using the Clustal V multiple alignment package within MEGALIGN (DNASTAR). International Union of Pure and Applied Chemistry (IUPAC) codes were used where appropriate 
Table 6. 1997 research cruise. Fish from which the tissue extracts were positive in the VHSV RT-PCR. Sampling site numbers correspond to those in Fig. 1

\begin{tabular}{|lll|}
\hline Sampling site & Sample number & Fish \\
\hline 3 Liverpool Bay & $23-41,23-42,23-44$ & Herring \\
5 Red Wharf Bay & $27-51,27-52,27-53$ & Herring \\
9 Lyme Bay & $39-55,39-56,39-58$ & Herring \\
15 Sole pit & $3-92,3-93$ & Cod \\
18 Flamborough & $13-104$ & Cod \\
19 Dogger & $18-110$ & Cod \\
\hline
\end{tabular}

All the initial 1:10 fish extracts were tested by the RTPCR for VHSV, and 6 pools from 2 sites were positive (Table 8). The products generated by RT-PCR (Fig. 6) were confirmed as VHSV by sequencing, and comparison of the partial sequences revealed 0 and 4 (0 to $1.5 \%$ ) nucleotide differences compared to the isolate made from herring in 1996 and the partial sequences obtained for the 1997 samples (Fig. 2).

The tissue extracts that were VHSV RT-PCR positive were inoculated onto 5 additional VHSV-susceptible cell lines (RTG-2, AS, SSN-1, RTE and TF) and pas- epithelioid layer surrounding necrotic tissue made up of phagocytic cells. Most granulomas contained significant amounts of pigmented material resembling lipofuscin finely distributed throughout the lesions. Ichthyophonus hoferi or bacteria were not observed.

\section{8 samples}

The fish species tested are shown in Table 7. One sample, 18-17 from haddock, exhibited CPE. The CPE was only seen in CHSE-214 cells pre-treated with PEG and incubated at $15^{\circ} \mathrm{C}$ for $25 \mathrm{~d}$ following a blind passage. The cells were frozen and thawed and passaged at $10^{-2}$ and $10^{-3}$ dilutions onto CHSE-214 cells with and without PEG pre-treatment, and incubated at 15 and $20^{\circ} \mathrm{C}$. CPE did not occur at $20^{\circ} \mathrm{C}$ and progressed slowly at $15^{\circ} \mathrm{C}$ affecting approximately $25 \%$ of the monolayer after $21 \mathrm{~d}$. The CPE occurred in the cells both with and without PEG pre-treatment, although more cells were affected if they had been pretreated with PEG. After a further passage CPE occurred more rapidly, and affected approximately $50 \%$ of PEG pre-treated cells and $25 \%$ of nontreated cells after incubation for $9 \mathrm{~d}$. The CPE exhibited as syncytia which gradually increased in size and eventually detached from the rest of the cell monolayer on the plastic substrate; the CPE was typical of that described for aquareoviruses (Lupiani et al. 1995) (Fig. 3). PEG concentrated virus was approximately $70 \mathrm{~nm}$ diameter and had a double-layered capsid (Fig. 4). The genome comprised 11 segments of double-stranded RNA (Fig. 5).
Table 7. Locations of fish sampled for virus detection in 1998. Sampling site numbers correspond to those in Fig. 1

\begin{tabular}{|c|c|c|c|}
\hline Sampling site & Location & $\begin{array}{c}\text { Fish } \\
\text { sampled }\end{array}$ & $\begin{array}{c}\text { Number } \\
\text { tested }\end{array}$ \\
\hline 14 Humber Off Ground & $53^{\circ} 53.21^{\prime} \mathrm{N}, 00^{\circ} 57.42^{\prime} \mathrm{E}$ & Sprat & 23 \\
\hline 14 Humber Off Ground & $53^{\circ} 53.21^{\prime} \mathrm{N}, 00^{\circ} 57.42^{\prime} \mathrm{E}$ & Cod & 15 \\
\hline 16 Humber Rough & $53^{\circ} 53.95^{\prime} \mathrm{N}, 00^{\circ} 15.46^{\prime} \mathrm{E}$ & Herring & 2 \\
\hline 16 Humber Rough & $53^{\circ} 53.95^{\prime} \mathrm{N}, 00^{\circ} 15.46^{\prime} \mathrm{E}$ & Cod & $36^{\mathrm{a}}$ \\
\hline 16 Humber Rough & $53^{\circ} 53.95^{\prime} \mathrm{N}, 00^{\circ} 15.46^{\prime} \mathrm{E}$ & Haddock & 20 \\
\hline 15 Sole Pit & $53^{\circ} 45.96^{\prime} \mathrm{N}, 01^{\circ} 24.04^{\prime} \mathrm{E}$ & Cod & 6 \\
\hline 15 Sole Pit & $53^{\circ} 45.96^{\prime} \mathrm{N}, 01^{\circ} 24.04^{\prime} \mathrm{E}$ & Whiting & 5 \\
\hline 15 Sole Pit & $53^{\circ} 45.96^{\prime} \mathrm{N}, 01^{\circ} 24.04^{\prime} \mathrm{E}$ & Herring & 4 \\
\hline 17 Flamborough Off Ground & $54^{\circ} 15.03^{\prime} \mathrm{N}, 00^{\circ} 03.96^{\prime} \mathrm{E}$ & Cod & 50 \\
\hline 17 Flamborough Off Ground & $54^{\circ} 15.03^{\prime} \mathrm{N}, 00^{\circ} 03.96^{\prime} \mathrm{E}$ & Herring & 50 \\
\hline 17 Flamborough Off Ground & $54^{\circ} 15.03^{\prime} \mathrm{N}, 00^{\circ} 03.96^{\prime} \mathrm{E}$ & Turbot & 3 \\
\hline 17 Flamborough Off Ground & $54^{\circ} 15.03^{\prime} \mathrm{N}, 00^{\circ} 03.96^{\prime} \mathrm{E}$ & Scad & 5 \\
\hline 17 Flamborough Off Ground & $54^{\circ} 15.03^{\prime} \mathrm{N}, 00^{\circ} 03.96^{\prime} \mathrm{E}$ & Brill & 2 \\
\hline 19 Dogger & $54^{\circ} 47.24^{\prime} \mathrm{N}, 01^{\circ} 17.15^{\prime} \mathrm{E}$ & Cod & 13 \\
\hline 19 Dogger & $54^{\circ} 47.24^{\prime} \mathrm{N}, 01^{\circ} 17.15^{\prime} \mathrm{E}$ & Herring & 3 \\
\hline 19 Dogger & $54^{\circ} 47.24^{\prime} \mathrm{N}, 01^{\circ} 17.15^{\prime} \mathrm{E}$ & Scad & 2 \\
\hline 20 Amble & $55^{\circ} 19.23^{\prime} \mathrm{N}, 01^{\circ} 15.09^{\prime} \mathrm{W}$ & Cod & $51^{\mathrm{a}}$ \\
\hline 20 Amble & $55^{\circ} 19.23^{\prime} \mathrm{N}, 01^{\circ} 15.09^{\prime} \mathrm{W}$ & Haddock & 28 \\
\hline 20 Amble & $55^{\circ} 19.23^{\prime} \mathrm{N}, 01^{\circ} 15.09^{\prime} \mathrm{W}$ & Herring & 1 \\
\hline 1 Dundrum Bay & $54^{\circ} 08.20^{\prime} \mathrm{N}, 05^{\circ} 37.27^{\prime} \mathrm{W}$ & Cod & 22 \\
\hline 1 Dundrum Bay & $54^{\circ} 08.20^{\prime} \mathrm{N}, 05^{\circ} 37.27^{\prime} \mathrm{W}$ & Herring & 50 \\
\hline 1 Dundrum Bay & $54^{\circ} 08.20^{\prime} \mathrm{N}, 05^{\circ} 37.27^{\prime} \mathrm{W}$ & Haddock & 2 \\
\hline 1 Dundrum Bay & $54^{\circ} 08.20^{\prime} \mathrm{N}, 05^{\circ} 37.27^{\prime} \mathrm{W}$ & Turbot & 1 \\
\hline 5 Red Wharf Bay & $53^{\circ} 21.42^{\prime} \mathrm{N}, 04^{\circ} 07.58^{\prime} \mathrm{W}$ & Herring & 50 \\
\hline 5 Red Wharf Bay & $53^{\circ} 21.42^{\prime} \mathrm{N}, 04^{\circ} 07.58^{\prime} \mathrm{W}$ & Cod & 20 \\
\hline 5 Red Wharf Bay & $53^{\circ} 21.42^{\prime} \mathrm{N}, 04^{\circ} 07.58^{\prime} \mathrm{W}$ & Turbot & 1 \\
\hline 5 Red Wharf Bay & $53^{\circ} 21.42^{\prime} \mathrm{N}, 04^{\circ} 07.58^{\prime} \mathrm{W}$ & Saithe & 1 \\
\hline 3 Liverpool Bay & $53^{\circ} 28.17^{\prime} \mathrm{N}, 03^{\circ} 42.59^{\prime} \mathrm{W}$ & Cod & 28 \\
\hline 3 Liverpool Bay & $53^{\circ} 28.17^{\prime} \mathrm{N}, 03^{\circ} 42.59^{\prime} \mathrm{W}$ & Herring & 20 \\
\hline 3 Liverpool Bay & $53^{\circ} 28.17^{\prime} \mathrm{N}, 03^{\circ} 42.59^{\prime} \mathrm{W}$ & Turbot & 1 \\
\hline 6 Cardigan Bay & $52^{\circ} 21.85^{\prime} \mathrm{N}, 04^{\circ} 54.23^{\prime} \mathrm{W}$ & Herring & 1 \\
\hline 6 Cardigan Bay & $52^{\circ} 21.85^{\prime} \mathrm{N}, 04^{\circ} 54.23^{\prime} \mathrm{W}$ & Brill & 3 \\
\hline 7 Carmarthen Bay & $51^{\circ} 32.49^{\prime} \mathrm{N}, 04^{\circ} 46.30^{\prime} \mathrm{W}$ & Cod & 17 \\
\hline 7 Carmarthen Bay & $51^{\circ} 32.49^{\prime} \mathrm{N}, 04^{\circ} 46.30^{\prime} \mathrm{W}$ & Turbot & 1 \\
\hline 7 Carmarthen Bay & $51^{\circ} 32.49^{\prime} \mathrm{N}, 04^{\circ} 46.30^{\prime} \mathrm{W}$ & Sea trout & 1 \\
\hline 7 Carmarthen Bay & $51^{\circ} 32.49^{\prime} \mathrm{N}, 04^{\circ} 46.30^{\prime} \mathrm{W}$ & Haddock & 1 \\
\hline 9 Lyme Bay & $50^{\circ} 33.34^{\prime} \mathrm{N}, 03^{\circ} 12.62^{\prime} \mathrm{W}$ & Cod & 5 \\
\hline 9 Lyme Bay & $50^{\circ} 33.34^{\prime} \mathrm{N}, 03^{\circ} 12.62^{\prime} \mathrm{W}$ & Sprat & 20 \\
\hline 9 Lyme Bay & $50^{\circ} 33.34^{\prime} \mathrm{N}, 03^{\circ} 12.62^{\prime} \mathrm{W}$ & Herring & $5^{\mathrm{b}}$ \\
\hline 10 Rye Bay & $50^{\circ} 50.79^{\prime} \mathrm{N}, 00^{\circ} 45.82^{\prime} \mathrm{E}$ & Turbot & 1 \\
\hline 10 Rye Bay & $50^{\circ} 50.79^{\prime} \mathrm{N}, 00^{\circ} 45.82^{\prime} \mathrm{E}$ & Cod & 40 \\
\hline 10 Rye Bay & $50^{\circ} 50.79^{\prime} \mathrm{N}, 00^{\circ} 45.82^{\prime} \mathrm{E}$ & Herring & $50^{\mathrm{b}}$ \\
\hline
\end{tabular}



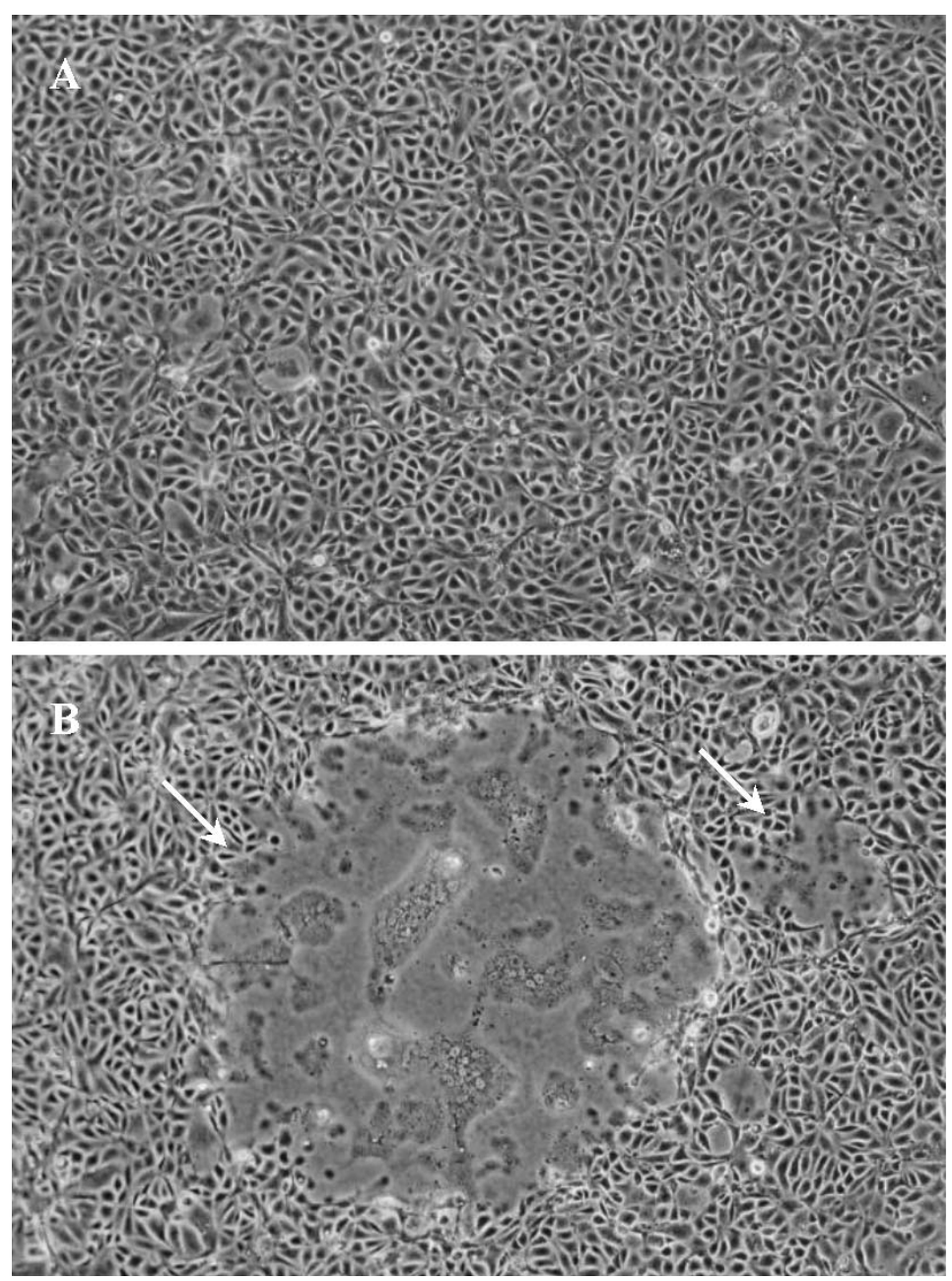

Fig. 3. CHSE-214 cells infected with Isolate 18-17. (A) control cells, (B) syncitia (arrowed) in infected cell culture

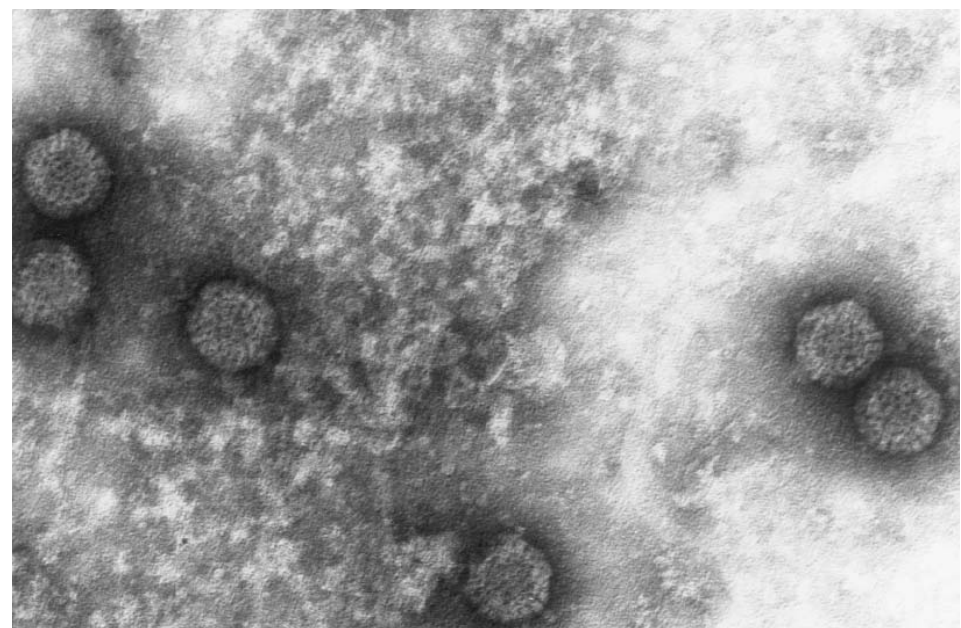

Fig. 4. Electron micrograph of negatively stained Isolate 18-17, concentrated from infected CHSE-214 cells by polyethylene glycol (PEG) precipitation. Virions are approximately $70 \mathrm{~nm}$ in diameter saged after $7 \mathrm{~d}$, but no CPE was observed. The original extract from Sample 24-3 produced a strong signal in the RT-PCR, and the BF-2, CHSE-214 and EPC cells harvested $7 \mathrm{~d}$ after inoculation with that material were tested by RT-PCR to determine whether VHSV may have replicated in the cells without producing any $\mathrm{CPE}$; however, the RTPCR was negative for the virus.

Several herring from Rye Bay had granular kidneys and spleens at post mortem. The histological appearance was similar to that described for herring spleens in 1997.

Data on the virus-positive samples recorded over the $4 \mathrm{yr}$ are summarised in Table 9 .

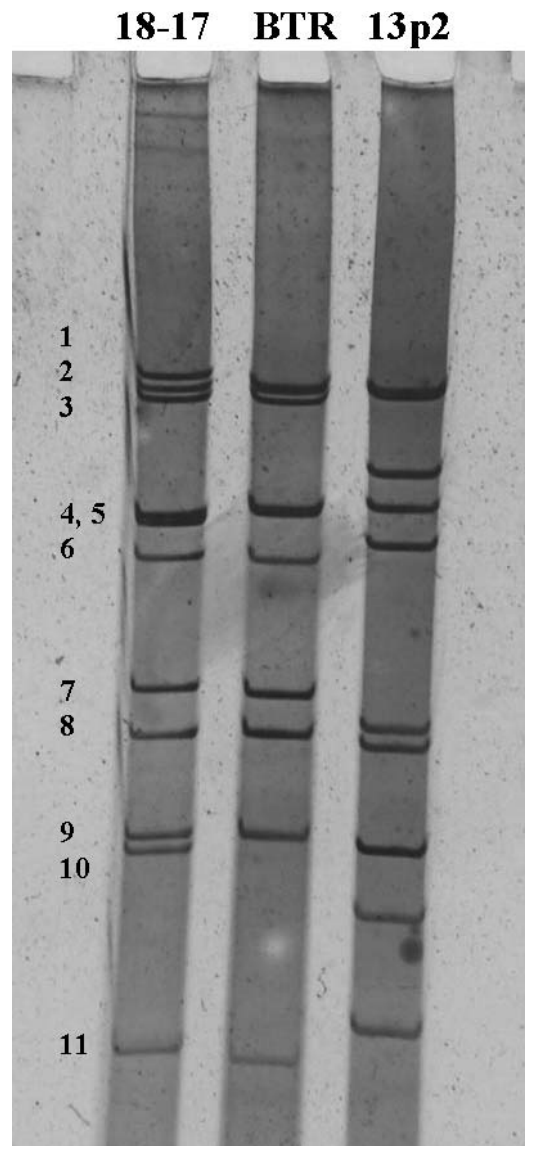

Fig. 5. Comparison of the RNA profiles of Isolate 18-17, BTR and $13 p 2$ aquareoviruses. The viruses were concentrated from infected CHSE-214 cells

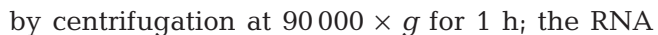
was extracted by the SDS-Proteinase $\mathrm{K}$ method and analysed on a $6 \%$ polyacrylamide gel. Electrophoresis was for $1.5 \mathrm{~h}$ at $200 \mathrm{~V}$, and the gel was silver stained. The RNA segments of Isolate 18-17 are numbered 


\section{$\begin{array}{llllllllll}1 & 2 & 3 & 4 & 5 & 6 & 7 & 8 & 9 & 10\end{array}$}

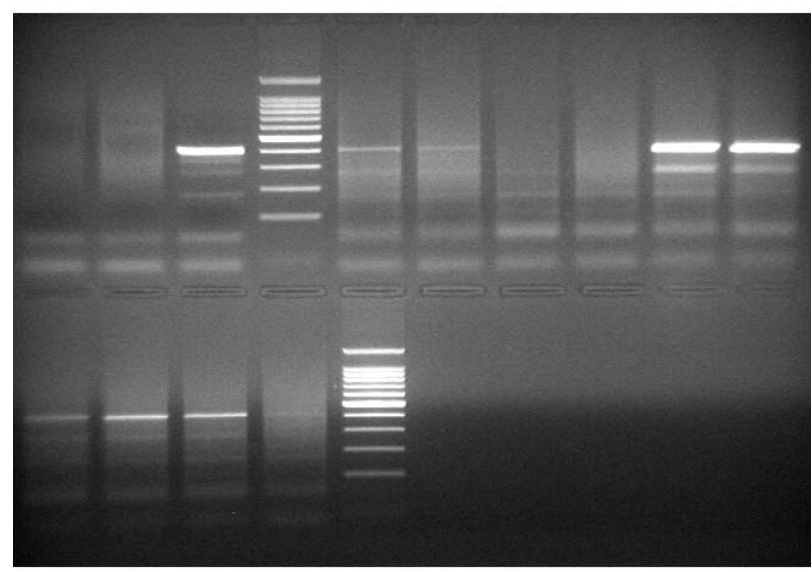

\section{$\begin{array}{lllll}11 & 12 & 13 & 14 & 15\end{array}$}

Fig. 6. Detection of the viral haemorrhagic septicaemia virus (VHSV) glycoprotein gene in herring tissue samples by seminested reverse transcription PCR (RT-PCR). Lanes 1 and 2: negative controls; lane 3: VHSV-positive control; lanes 4 and 15: 100 bp ladders (Promega); lanes 5 to 14: paired samples corresponding to Isolates 24-1,24-2, 24-3, 24-4 and 24-5 respectively

Table 8. 1998 research cruise. Fish from which the tissue extracts were positive in the viral haemorrhagic septicaemia virus (VHSV) reverse transcription PCR (RT-PCR). Sampling site numbers correspond to those in Fig. 1

\begin{tabular}{|lll|}
\hline Sampling site & Sample number & Fish \\
\hline 5 Red Wharf Bay & $24-1,24-3,24-4,24-5,24-6$ & Herring \\
10 Rye Bay & $43-6$ & Herring \\
\hline
\end{tabular}

\section{DISCUSSION}

The sample sizes of some fish species in these surveys were small, which was a consequence of the virological sampling being an adjunct to the main survey; however, the numbers of fish sampled increased over the years (Table 1). Despite the limitations of sample size, in 2 of the years viruses were isolated. The isolation of VHSV from herring and its identification in herring tissues by RT-PCR has been reported in more detail elsewhere (Dixon et al. 1997), but fish catch data from that cruise have been included here to provide a complete picture of the $4 \mathrm{yr}$ sampling programme. It was interesting to note that a birnavirus, Serotype B1, was isolated from cod from the same location, Rye Bay (Site 10), the following year (1997). However there is nothing to suggest that this is more than a coincidence. Cod from Carmarthen Bay (Site 7) were positive for a serologically distinct birnavirus belonging to Serotype A2. Birnaviruses have been isolated from cod fry in culture in Danish coastal waters and from cod fry in culture on the Faroe islands (Lorenzen et al. 1995); the viruses from those 2 locations also belonged to Serotype A2 (N. J. Olesen pers. comm.). On both those occasions the cod were undergoing mortalities, but there was no indication that the older cod from which the birnaviruses were isolated in this study were diseased.

A birnavirus belonging to Serotype B1 was also isolated from herring (a previously unrecorded host) from Liverpool Bay (Site 3), again in 1997. The significance of these birnavirus isolates for their respective hosts is unknown. Further work is necessary to determine the effect that the birnaviruses and the aquareovirus may have on species in coastal aquaculture or ranching. Birnavirus Serotype B1 has previously been isolated from marine invertebrates, but until recently it had only been isolated from 1 marine fish species, the dab (Olesen et al. 1988). However, reports of similar marine fish surveys have shown that Serotype B1 has been recorded from a wide range of marine fish, predominantly flatfish (Mortensen et al. 1999, Skall et al. 2000).

In 1998 an aquareovirus was isolated from haddock (a previously unrecorded host) which showed no external or internal clinical signs. The pattern of RNA segments of the haddock aquareovirus is similar to that of BTR, which was isolated from a brown trout (sea trout) that had returned to freshwater from the marine environment (Taylor et al. 1998). The haddock were caught off the east coast of the UK, and the brown trout was captured in a river whose mouth is on the west coast of the UK. To what extent these isolates may represent a pool of similar aquareoviruses in fish in the marine environment around the UK is unknown.

Table 9. Summary of fish species sampled during the 4 research cruises from which the tissue extracts were virus-positive by isolation in cell culture or by reverse transcription PCR (RT-PCR). VHSV: viral haemorrhagic septicaemia virus

\begin{tabular}{|c|c|c|c|c|}
\hline Sampling site & Year & Fish & Virus & $\begin{array}{l}\text { Detection } \\
\text { method }\end{array}$ \\
\hline 10 Rye Bay & 1996 & Herring & VHSV & Isolation \\
\hline 3 Liverpool Bay & 1997 & Herring & Birnavirus B1 & Isolation \\
\hline 7 Carmarthen Bay & 1997 & Cod & Birnavirus A2 & Isolation \\
\hline 10 Rye Bay & 1997 & Cod & Birnavirus B1 & Isolation \\
\hline 3 Liverpool Bay & 1997 & Herring & VHSV & RT-PCR \\
\hline 5 Red Wharf Bay & 1997 & Herring & VHSV & RT-PCR \\
\hline 9 Lyme Bay & 1997 & Herring & VHSV & RT-PCR \\
\hline 15 Sole pit & 1997 & Cod & VHSV & RT-PCR \\
\hline 18 Flamborough & 1997 & Cod & VHSV & RT-PCR \\
\hline 19 Dogger & 1997 & Cod & VHSV & RT-PCR \\
\hline 20 Amble & 1998 & Haddock & Aquareovirus & Isolation \\
\hline 5 Red Wharf Bay & 1998 & Herring & VHSV & RT-PCR \\
\hline 10 Rye Bay & 1998 & Herring & VHSV & RT-PCR \\
\hline
\end{tabular}


VHSV was not isolated in cell cultures in 1997, but 13 samples were RT-PCR positive for the virus nucleic acid. The positive samples were from herring from 3 sites on the west and south coasts of England and from cod from 3 sites on the east coast of England. Low numbers of VHSV-positive cod were caught at each site and low numbers of positive herring were caught in Lyme Bay, which might indicate a high prevalence of VHSV in those sites. When VHSV was isolated from the herring in 1996, it was only isolated in BF-2 cells; EPC cells inoculated with the same samples were refractory to the virus. It is therefore possible that both cell lines may have been refractory to the VHSV detected by RT-PCR in 1997. In order to investigate that supposition further, 2 additional cell lines were used in 1998, and PEG pre-treatment of the cells (Batts \& Winton 1989) was also used to increase the sensitivity of the isolation method. A greater number of fish were also sampled in 1998. However, VHSV was not isolated in 1998 but again the RT-PCR showed the presence of VHSV nucleic acid in herring from 2 sampling sites. Although there are only data for $2 \mathrm{yr}$, the RT-PCR data suggest that the prevalence of VHSV varies both spatially and temporally. Longer term studies are required to establish whether VHSV is consistently found in the same sites, and the nature of any temporal trend in prevalence. In 1997, both cod and herring were caught at the same sites where RT-PCR positive fish were identified, but cod caught at the same site as RT-PCR positive herring were RT-PCR negative and vice versa. Likewise in 1998, cod caught at the same sites as the RT-PCR positive herring were RT-PCR negative. That consistent feature may have significance for the epidemiology of VHSV in the marine environment, particularly the transmission of VHSV between the 2 species.

Very few of the fish examined showed gross external signs of disease. Three cod exhibited skin ulcers but were negative for VHSV. The initial isolation of VHSV from Atlantic cod was from ulcerated individuals (Jensen et al. 1979), but VHSV has only been isolated at a low frequency from such fish in later studies, and any relationship between VHSV and the cod ulcers is unresolved (Mortensen et al. 1999, Smail 2000, King et al. 2001). Likewise, Meyers et al. (1992) isolated VHSV from ulcerated skin lesions from Pacific cod Gadus macrocephalus. The authors noted the association of virus with the skin lesions, but were unable to determine whether the virus was the primary cause of the lesion, or a secondary pathogen. In one case the lesion appeared to be caused by an inflammatory host response to a possible protozoan parasite. Low numbers of the RT-PCR-positive herring had spleens and/or kidneys containing granulomas, but such fish were also observed in samples that were RT-PCR negative, and fish without such pathology were RT-PCR positive. No specific association of RT-PCR-positive herring and the presence of granulomas can be made because of the low numbers of fish with granulomas. The cause of the granulomas remains unresolved, but similar nonspecific granulomatous inflammation was observed in a survey of Pacific herring Clupea pallasi in Alaskan waters (Marty et al. 1998).

Comparisons of the nucleotide sequences of the RTPCR products from the herring and cod samples with those of other VHSV isolates showed that they should be categorised as belonging to Genogroup III (Stone et al. 1997). Their nucleotide sequences were identical to, or differed by up to $1.5 \%$ from the nucleotide sequence of the 1996 isolate from herring from the south coast of England (Dixon et al. 1997). Further isolates of VHSV from 5 different fish species, including herring and cod, from around northern UK (Scottish coastal waters and the northern North Sea) were genetically similar to a Genogroup II isolate from turbot (King et al. 2001). This 'north-south divide' in the genetic difference between VHSV from around the UK may be maintained by the geographic separation of different populations of the host species. King et al. (2001) did not isolate VHSV in 1997, but made 21 isolations from fish caught in 1998, of which 17 were from Norway pout Trisopterus esmarkii and 1 each were from cod, herring, whiting and poor cod. Smail $(1995,2000)$ reported the isolation of VHSV from cod (2 in 1993 and 1 in 1995) and from 2 haddock in 1995, from coastal waters off eastern Scotland. In the study reported here, the greater number of RT-PCR-positive sites was recorded in 1997 (3 each for cod and herring), and the greatest prevalence was in herring. No Norway pout were captured in this study; the areas trawled on the east coast of the UK in the North Sea were at or below the southernmost range of significant populations of Norway pout. The Norway pout may be an important reservoir of Genogroup II VHSV in northern UK waters, but the herring, or an as yet unidentified host species, may be the main reservoir of Genogroup III VHSV in southern UK waters.

The reason why VHSV could not be isolated from samples which were RT-PCR positive cannot be specifically determined. The cells used supported the replication of cell-culture adapted VHSV, and the virus was isolated from tissues from VHSV-infected rainbow trout in the BF-2, FHM and EPC cells in laboratory tests (results not shown). This leads to the conclusion that (1) there was no viable virus present in the fish tissues (it could have lost viability during storage or it could have been inactivated by host defence mechanisms), (2) virus was present, but at levels below the sensitivity of the isolation method, or (3) that some marine VHSV does not grow as readily in cell cultures 
as the freshwater VHSV. That possible latter phenomenon should be borne in mind when marine fish are screened for VHSV, and samples should also be screened by the RT-PCR; otherwise there may be an underestimation of the prevalence of the virus. The freezing and thawing of the fish viscera prior to processing might have accounted for the loss of viability of VHSV in some of the samples, but it is known that the virus will survive such treatment, as shown by isolation of VHSV from frozen tissues in this study in 1996, and in other reports (Meyers et al. 1994, 1999, Mortensen et al. 1999, Smail 2000, King et al. 2001). Red Wharf Bay and Rye Bay appear to be 'hot spots' of VHSV in herring, and we intend to take more herring samples from those sites to investigate further the inability of the VHSV to grow in cell culture.

Acknowledgements. We thank Mr. Edmund Peeler for his helpful comments on the epidemiological data. This work was supported by Defra contracts F0431, CSA 3342, F1118 and AE003.

\section{LITERATURE CITED}

Batts WN, Winton JR (1989) Enhanced detection of infectious hematopoetic necrosis virus and other fish viruses by pretreatment of cell monolayers with polyethylene glycol. J Aquat Anim Health 1:284-290

Bucke D, Vethaak AD, Lang D, Mellergaard S (1996) Common diseases and parasites of fish in the North Atlantic: training guide for identification. ICES Techniques in Marine Environmental Sciences, No. 19. International Council for the Exploration of the Sea, Copenhagen

CEC (1992) Commission Decision 92/532/EC. Sampling and testing procedures for VHS and IHN monitoring. Off J Eur Comm L 337:18-27

CEC (1996) Commission Decision 96/240/EC. Sampling and testing procedures for VHS and IHN monitoring. Off J Eur Comm L 79:19-28

Dixon PF, de Groot J (1996) Detection of rainbow trout antibodies to infectious pancreatic necrosis virus by an immunoassay. Dis Aquat Org 26:125-132

Dixon PF, Hill BJ (1983) Rapid detection of infectious pancreatic necrosis virus (IPNV) by the enzyme-linked immunosorbent assay (ELISA). J Gen Virol 64:321-330

Dixon PF, Feist S, Kehoe E, Parry L, Stone DM, Way K (1997) Isolation of viral haemorrhagic septicaemia virus from Atlantic herring Clupea harengus from the English Channel. Dis Aquat Org 30:81-89

Fijan N, Sulimanovic D, Bearzotti M, Muzinic D, Zwillenberg LO, Chilmonczyk S, Vautherot JF, Kinkelin Pd (1983) Some properties of the Epithelioma papulosum cyprini (EPC) cell line from carp Cyprinus carpio. Ann Virol (Inst Pasteur) 134:207-220

Frerichs GN, Morgan D, Hart D, Skerrow C, Roberts RJ, Onions DE (1991) Spontaneously productive C-type retrovirus infection of fish cell lines. J Gen Virol 72:2537-2539

Higgins DG, Sharp PM (1989) Fast and sensitive multiple sequence alignments on a microcomputer. CABIOS 2: 151-153

Hill BJ (1976) Properties of a virus isolated from the bivalve mollusc Tellina tenuis (da Costa). In: Page LA (ed) Wildlife diseases. Plenum Press, New York, p 445-452
Hill BJ, Way K (1995) Serological classification of infectious pancreatic necrosis (IPN) virus and other aquatic birnaviruses. Annu Rev Fish Dis 5:55-77

Jensen MH (1965) Research on the virus of Egtved disease. Ann NY Acad Sci 126:422-426

Jensen NJ, Bloch B, Larsen JL (1979) The ulcus-syndrome in cod (Gadus morhua). III. A preliminary virological report. Nord Vet Med 31:436-442

Jørgensen PEV, Bregnballe F (1969) Infectious pancreatic necrosis in rainbow trout (Salmo gairdneri) in Denmark. Nord Vet Med 21:142-148

Jørgensen PEV, Olesen NJ (1987) Cod ulcus syndrome rhabdovirus is indistinguishable from the Egtved (VHS) virus. Bull Eur Assoc Fish Pathol 7:73-74

King JA, Snow M, Smail DA, Raynard RS (2001) Distribution of viral haemorrhagic septicaemia virus in wild fish species of the North Sea, north east Atlantic Ocean and Irish Sea. Dis Aquat Org 47:81-86

Lorenzen E, Olesen NJ, Strøm A, Evensen Ø (1995) Outbreaks of IPN in reared fry of Atlantic cod (Gadus morhua). EAFP 7th Int Conf Diseases of Fish and Shellfish (Abs) 38. European Association of Fish Pathologists, Palma de Mallorca

Lupiani B, Subramanian K, Samal SK (1995) Aquareoviruses. Annu Rev Fish Dis 5:175-208

Marty GD, Freiberg EF, Meyers TR, Wilcock J, Farver TB, Hinton DE (1998) Viral hemorrhagic septicemia virus, Ichthyophonus hoferi, and other causes of morbidity in Pacific herring Clupea pallasi spawning in Prince William Sound, Alaska, USA. Dis Aquat Org 32:15-40

Meier W, Schmitt M, Wahli T (1994) Viral hemorrhagic septicemia (VHS) of nonsalmonids. Annu Rev Fish Dis 4: $359-373$

Meyers TR (1979) A reo-like virus isolated from juvenile American oysters (Crassostrea virginica). J Gen Virol 43 203-212

Meyers TR, Winton JR (1995) Viral hemorrhagic septicemia virus in North America. Annu Rev Fish Dis 5:3-24

Meyers TR, Sullivan J, Emmenegger E, Follett J, Batts WN, Winton JR (1992) Identification of viral hemorrhagic septicaemia virus isolated from Pacific cod Gadus macrocephalus in Prince William Sound, Alaska, USA. Dis Aquat Org 12:165-175

Meyers TR, Short S, Lipson K, Batts WN, Winton JR, Wilcock J, Brown E (1994) Association of viral hemorrhagic septicemia virus with epizootic hemorrhages of the skin in Pacific herring Clupea harengus pallasi from Prince William Sound and Kodiak Island, Alaska, USA. Dis Aquat Org 19:27-37

Meyers TR, Short S, Lipson, K (1999) Isolation of the North American strain of viral hemorrhagic septicemia virus (VHSV) associated with epizootic mortality in 2 new host species of Alaskan marine fish. Dis Aquat Org 38:81-86

Mortensen HF, Heuer OE, Lorenzen N, Otte L, Olesen NJ (1999) Isolation of viral haemorrhagic septicaemia virus (VHSV) from wild marine fish species in the Baltic Sea, Kattegat, Skagerrak and the North Sea. Virus Res 63: 95-106

Munro ALS (1996) First recorded outbreak of viral haemorrhagic septicaemia (VHS) in GB and subsequent actions to contain, eradicate and investigate the origins of the infection. Scottish Office Agriculture, Environment and Fisheries Department. Scottish Aquaculture Research Report No. 3, Aberdeen

Nicholson BL, Byrne C (1973) An established cell line from the Atlantic salmon (Salmo salar). J Fish Res Board Can 30 913-916 
Olesen NJ, Jørgensen PEV, Bloch B, Mellergaard S (1988) Isolation of an IPN-like virus belonging to the serogroup II of the aquatic birnaviruses from dab, Limanda limanda L. J Fish Dis 11: 449-451

Rovozzo GC, Burke CN (1973) A manual of basic virological techniques. Prentice Hall, Englewood Cliffs, NJ

Skall HF, Mellergaard S, Olesen NJ (2000) Isolation of Birnavirus serogroup B in wild and aquacultured fish species. Bull Eur Assoc Fish Pathol 20: 229-236

Smail DA (1995) Isolation and identification of viral haemorrhagic septicaemia (VHS) virus from North Sea cod (Gadus morhua L.). International Council for the Exploration of the Sea, Mariculture Committee, Copenhagen, CM 1995/F15, p 1-5

Smail DA (2000) Isolation and identification of Viral Haemorrhagic Septicaemia (VHS) viruses from cod Gadus morhua with the ulcus syndrome and from haddock Melanogrammus aeglefinus having skin haemorrhages in the North Sea. Dis Aquat Org 41: 231-235

Stone DM, Way K, Dixon PF (1997) Nucleotide sequence of

Editorial responsibility: Jo-Ann Leong,

Kaneohe, Hawaii, USA the glycoprotein gene of viral haemorrhagic septicaemia (VHS) viruses from different geographical areas: a link between VHS in farmed fish species and viruses isolated from North Sea cod (Gadus morhua L.). J Gen Virol 78: $1319-1326$

Strømmen HK, Stone DM (1998) Detection of viral haemorrhagic septicaemia (VHS) virus in fish tissues by seminested polymerase chain reaction (PCR). In: Barnes AC, Davidson GA, Hiney MP, McIntosh D (eds) Methodology in fish diseases research. Fisheries Research Services, Aberdeen, p 203-209

Taylor G, Forrest A, Stone DM, Way K (1998) Isolation of an aquareovirus from brown trout (Salmo trutta) in the United Kingdom. Fourth Int Symp Viruses of Lower Vertebrates (Abs) PP02. CEFAS, Weymouth

Way K (1996) Development of a rapid dipstick-format field test for VHS virus. Bull Eur Assoc Fish Pathol 16: 58-62

Way K, Dixon PF (1988) Rapid detection of VHS and IHN viruses by the enzyme-linked immunosorbent assay (ELISA). J Appl Ichthyol 4: 182-189

Submitted: April 10, 2002; Accepted: November 1, 2002 Proofs received from author(s): March 21, 2003 